Sanita Osipova, Dr. iur., Professor

University of Latvia

\title{
ESTABLISHING THE UNIVERSITY OF LATVIA
}

\begin{abstract}
Summary
During the Soviet occupation, it was emphasised that the University of Latvia had been founded by the head of the Latvian Socialist Soviet Republic P. Stučka on 8 February 1919. Research has uncovered that the following dates in the establishing of the University of Latvia should be recognised as important from the legal perspective: the decision of the People's Council of Latvia of 15 July 1919 on establishing the Latvian Higher School, and the order of 3 August of the Provisional Government of Latvia "On taking over Riga Polytechnical Institute". These decisions and not the decree of Stučka paved the legal grounds for the opening of the University of Latvia on 28 September 1919.
\end{abstract}

Keywords: national higher school, the University of Latvia, the Latvian State University

\section{Introduction}

During the Soviet occupation, it was emphasised that the University of Latvia had been founded by the head of the Latvian Socialist Soviet Republic Pèteris Stučka (1865-1932), and 8 February $1919^{1}$ was indicated as the date of its foundation. It was further explained that, later on, "in the bourgeois Latvia", the University of Latvia had been formed on the basis of the higher school founded by Stučka. ${ }^{2}$ This Soviet myth, according to which the University of Latvia was the very same Latvian Higher School founded by Stučka, remained unrevised even at the time of the Atmoda [the Awakening]. Ilgonis Bite wrote the following on 4 February 1989 to honour the $70^{\text {th }}$ anniversary of the University of Latvia:

[..] the Bolshevik men in power paid most serious attention to the establishment and formation of a higher school, and, already about a month after their entry in Riga, issued a decree (dated 8 February 1919, signed by Pêteris Stuckka) on the Higher School of the Soviet Latvia [..] The first chord in the emergence of the Latvian State University was thus struck. In its turn, the opening of the Latvian Higher School took place on 28 September 1919, with the participation of the President of the People's Council Jānis Čakste. ${ }^{3}$

1919. gada 8. februāra Latvijas Sociālistiskās valdības dekrēts "Par Latvijas augstskolas dibināšanu" [The Decision of the Latvian Socialist Government "On the Establishment of the Latvian Higher School”]. In: Cinna, No. 26, 08.02.1919, p. 1.

2 Pētera Stučkas Latvijas Valsts universitāte 40 gados (1919-1959) [Pēteris Stučka’s Latvian State University in 40 years (1919-1959)]. Jurgens J. (ed.), Riga: Latvijas valsts izdevnieciiba, 1959, pp. 3, 4.

3 Bite I. P. "Celdamās augstāki”. Stučkas Latvijas Valsts Universitātei 70 ["Rising higher". Stučka’s Latvian State University Turns 70]. In: Literatūra un Māksla, No. 5, 04.02.1989, p. 2. 
In this concept, the establishment of the University was divided into two parts, with Pēteris Stučka laying the legal foundation, and Jānis Čakste (1859-1927) accomplishing the actual opening. This is rather illogical from both the historic and the legal perspective. Stučka and Čakste represented two different and mutually negating states. Thirty years have passed since the Atmoda period, and the legal twists and turns in establishing the University of Latvia should have been figured out by now. However, what we find in Wikipedia is exactly the same text from the 1989 publication as cited above. ${ }^{4}$ This seems to lack importance, as we are aware that Wikipedia is not a reliable source, but in the Constitution of the University of Latvia we have the same explanation of University's establishment. ${ }^{5}$

A number of books about the University of Latvia has been published to date. Every anniversary of the University sees a solemn launch of a new book. This tradition, which was started in the interwar period of the $20^{\text {th }}$ century, more precisely, in 1929 , when the $10^{\text {th }}$ anniversary of the UL was celebrated, continued during the years of the Soviet power, as well as after the restoration of independence of the Republic of Latvia. ${ }^{6}$ The books seem to be concerned with one and the same higher education institution, yet there are substantial differences not only between the names for the institution and its public tasks, but also between the facts about the establishment of the university and the continuity of institutions, namely, whether the University of Latvia established by the Republic of Latvia is the successor of the Latvian Higher School founded by Pēteris Stučka's government of the Latvian Soviet Socialist Republic, or, as it was written in the Soviet literature, the two universities are one and the same. This question is further complicated by the fact that the University of Latvia was also first established as the Latvian Higher School, ${ }^{7}$ and both of the aforementioned names were used interchangeably for several years after the establishment of the institution (until 1923). ${ }^{8}$

4 Latvijas Universitāte [University of Latvia]. In: Wikipedia. Available at: https://lv.wikipedia.org/ wiki/Latvijas_Universit\%C4\%81te [last viewed July 11, 2019].

5 Latvijas Universitātes Satversme pieņemta LU Satversmes sapulces sēdē 29.03.96. un grozijumi, kas pieñemti LU Satversmes sapulces sēdē 16.12.96., LU Satversmes sapulces sēdē 10.05.2001, LU Satversmes sapulcē 22.02.2006. [The Constitution of the University of Latvia was adopted at a meeting of the Constituent Assembly of the University of Latvia on March 29, 1996, and amendments adopted at a meeting of the Constituent Assembly of the University of Latvia December 16, 1996, at a meeting of the Constituent Assembly of the University of Latvia May 10, 2001, at the Constituent Assembly of the University of Latvia February 22, 2006]. Available at: https://likumi.lv/doc.php?id=46864 [last viewed September 26, 2019].

6 Latvijas Universitāte 1919.-1929. [University of Latvia. 1919-1929]. Rīga: Latvijas Universitātes izdevums, 1929, Latvijas Universitāte 20 gados 1919-1939. [University of Latvia in 20 years. 19191939. Part I]. Rīga: Latvijas Universitāte, I daļa, 1939, Latvijas Universitāte 20 gados 1919-1939. [University of Latvia in 20 years. 1919-1939. Part II] Riga: Latvijas Universitāte, II daļa, 1939, Pētera Stučkas Latvijas Valsts universitāte 40 gados (1919-1959). Jurgens J. (ed.), Rīga: Latvijas valsts izdevnieciba, 1959, etc.

7 The Commission for Organising the Latvian Higher School was created on 1 September 1919, LVVA 7427. f. 6. apr. 325. lieta, p. 80. The press, too, wrote about the establishment of the Latvian Higher School, e.g.: Latvijas Augstskola. In: Sociäldemokrāts, No. 75, 29.09.1919, p. 1.

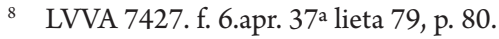


This year is the centenary of the University of Latvia, and in this research the author will analyse regulations, shorthand reports of the sittings of the People's Council of Latvia, the surviving documents of the Council for Organising the University of Latvia, as well as other archive and press materials, to study the process of establishing the University of Latvia.

\section{The three governments in Latvia 1918/1919 and their universities}

In $1918 / 1919$, three statehoods were established in what is now the territory of Latvia. Some other statehood ideas were also considered at the time, floating around with no attempt being made to implement them - for example, a state of the Balts, i.e. Latvians and Lithuanians. ${ }^{9}$ Tumultuous as the end-of-war time was, it did not prevent every power that felt a halfway safe governor of the territory of Latvia from expeditiously addressing the top-priority tasks, the first of which was to establish an own higher school.

"In the waning years of World War I (1917-1918), the thought about the times of the "Livonian Order's omnipotence" came alive again with a new vigour. This conviction was bolstered by the presence in the Baltic of Kaiser's Germany's occupation military force, by the collapse of the Russian Empire and the Bolsheviks coming to power in Russia." ${ }^{10}$ The German Kaiser acknowledged the sovereignty of Vidzeme, Estonia, Riga and Saaremaa on 22 September 1918. ${ }^{11}$ This news reached the addressees only on 17 October, and the members of the independent commission of the United Land Council, based on the German communication of 22 September, decided to start activities for the formation of the Baltic Duchy, inviting the Duchy of Kurzeme to participate. ${ }^{12}$ Concurrently with the formation of the state, work was being done to create an appropriate higher school. Thus, in October 1918 the German occupation power renewed RPI as the Baltic Technical Higher School (German: Baltische Technische Hochschule), adjusting it to the German Empire's requirements for higher education institutions. This process could be complicated, because RPI, in the same way as plants and factories, had been evacuated during World War I deeper into the empire away from the front line, and all the RPI resources - either material or human - were no longer available in Riga. The stipulated language of instruction at the Baltic Technical Higher School was German. The statutes of the higher school

9 Lazdiņš J. Konstitucionālisma pirmsākumi un nerealizētie valstiskumi Latvijā [The beginning of constitutionalism and unrealized statehoods in Latvia]. In: Jurista Vārds. No 23 (774), 11.06.2013. Available at: https://juristavards.lv/doc/257350-konstitucionalisma-pirmsakumi-un-nerealizetievalstiskumi-latvija/ [last viewed July 10, 2019].

10 Ibid.

11 Wilhelm I. Graf von Hertling. Anerkennung der Unabhängigkeit von Livland, Estland, Riga und Oesel durch das Deutsche Reich. In: Rigische Zeitung, No. 243, 19.10.1918, p. 1.

12 Lazdiņš J., 2013. 
were approved by the German Military Administration on 15 October $1918 .{ }^{13}$ On 18 October 1918, the periodical Rigische Nachrichten informed that Kaiser Wilhelm I had sent a telegram with greetings to the newly established Baltic Technical Higher School. ${ }^{14}$

The thought about their own independent state had grown in the national selfconsciousness of Latvians. Therefore, simultaneously with the attempts to renew Livonia, that is, in the autumn of 1918, Latvian national political forces were trying to gain Germany's support for Latvian independence, so that Germany "would not throw obstacles in the way of the Latvian people to the immediate start of building an independent state." ${ }^{15}$ On 18 November 1918, Latvian national political forces, formed into the People's Council of Latvia, proclaimed the Republic of Latvia. ${ }^{16}$

Professor Jānis Lazdiņš writes: “On the very same day that the People’s Council proclaimed the Republic of Latvia, "other Latvian people" - Bolsheviks - decided at the $17^{\text {th }}$ Conference of the Latvian Social-Democracy that "Latvia is a connected commune, a constituent of the Russian Socialist Federative Soviet Republic, [and that] the Latvian issue is only resolvable in the interests of the proletariat along with the consolidation in Latvia of the power of the proletariat, which is only possible through international socialist revolution."' 17 On 17 December 1918, the Latvian Soviet Socialist Republic was proclaimed. ${ }^{18}$ On 3 January 1919, the Bolshevik forces entered Riga and took over almost the entire territory of Latvia in a short time. Thus, shortly after the proclamation of the Republic of Latvia, the Latvian Socialist Soviet Republic was proclaimed to be ruled by Pēteris Stučka's government. ${ }^{19}$ Stučka's government, too, appreciated the national importance of education. Therefore, one of its first steps was to reform the education system in accordance with the Marxist views: education must not be influenced by any religion and must be available to everyone on completely equal terms. Thus, it was established that education in all schools was free, and religious education in schools was prohibited. All Latvian schoolteachers had to be elected by the councils of workers' and landless peasants'

13 Zigmunde A. Baltijas Tehniskā augstskola [Baltic Technical University]. In: Zinātņu vēsture un muzejnieciba. LU raksti, Vol. 639, Rīga: LU, 2001, p. 36.

14 Kaisertelegramm an die Baltische Technische Hochschule. In: Rigische Zeitung, No. 242, 18.10.1918, p. 1.

15 LVVA 6033, f. 1. apr. 35, pp. 1, 57.

16 1918. gada 18. novembra Latvijas Tautas Padomes uzsaukums: Latvijas pilsoniem! [The address by the People's Council of Latvia on 18 November 1918: to the nationals of Latvia!]. In: Latvijas valsts tiesību avoti. Valsts dibināšana - neatkarības atjaunošana. Dokumenti un komentāri. Rỉga: Tiesu namu ağentūra, 2015, p. 54.

17 Lazdiņš J., 2013.

18 Pētera Stučkas Latvijas Valsts universitāte 40 gados (1919-1959), 1959, p. 7.

19 Bleiere D., Butulis I., Feldmanis I., Stranga A., Zunda A. Latvijas vēsture 20. gadsimts [History of Latvia $20^{\text {th }}$ Century]. Otrais papildinātais izdevums. Riga: Jumava, 2005, p. 113. 
deputies. ${ }^{20}$ The reform introduced the Latvian language in the system of education in addition to Russian as the language of instruction. ${ }^{21}$

On 8 February 1919, RPI was closed down by a decree signed by Pēteris Stučka: "its professors, assistants, service staff and other employees shall be considered (as of today) dismissed."22 In its stead, the Latvian Higher School was established and transferred to the jurisdiction of the Commissariat of Education ${ }^{23}$ headed by Jānis Bērziñ̌̌ (1881-1938). ${ }^{24}$ In a 1959 book about the University of Latvia, the need for a new higher school was explained, as follows: "Even though Riga Polytechnical Institute was located in the territory of Latvia, it could not be viewed as a Latvian national higher school. All training in it before 1896 was carried out in German, and after 1896 - in Russian. [..] And, what is especially important, the Institute did not satisfy, or plan to satisfy, Latvia's need for specialists in medicine, humanities and other branches of science and arts; it was mainly preparing engineers." ${ }^{25}$ Consequently, the LSSR also understood the necessity for higher education in Latvian allowing to prepare specialists needed by the state. Hence, in this respect, there is no particular contradiction with the concept that every state needs its own university. There was, however, a substantial departure from the requirements for classical higher education - before everything else, in the candidate admission requirements set out in the Commissariat of Education Regulation of 8 February 1919 on the Latvian Higher School. Not only did it contain the gender equality principle and age restrictions, namely, it granted the right to study from the age of 16, but it also included the provision that students should be admitted "without certificates of previous education, and no admission exams are held." ${ }^{26}$ Thus, an age prerequisite and not the literacy requirement was set for studying at the Higher School. While only gymnasium graduates are normally admitted to classical university, Stučka's government did not set such requirements for admission to the Latvian Higher School. Nor were any education or work experience criteria set for selecting the Higher School teachers. ${ }^{27}$ In other words, although a higher school was founded, it cannot be firmly concluded from the requirements for teachers and candidates that it was a full-scale university, that is, a higher education institution where an individual under the tutelage of professors continues education after graduating from secondary school. Rather, it was either a peculiar communist alternative to a classical bourgeois university, ensuring a possibility to study for all those willing, or a model

20 Pētera Stučkas Latvijas Valsts universitāte 40 gados (1919-1959), 1959, p. 8.

21 1919. gada 8. februāra LSPR Izglìtibas komisariāta noteikumi par Latvijas Augstskolu [February 8, 1919 Regulations of the LSSR Education Commission on the Latvian Higher School]. In: Cinna, No. 26, 08.02.1919, p. 1.

22 1919. gada 8. februāra Latvijas Sociālistiskās valdības dekrēts "Par Latvijas augstskolas dibināšanu" [The Decision of the Latvian Socialist Government "On the Establishment of the Latvian Higher School”]. In: Ciña, No. 26, 08.02.1919, p. 1.

23 Ibid.

${ }^{24}$ Latvijas enciklopēdija [Latvian Encyclopaedia]. $1^{\text {st }}$ volume. Rīga: Valērija Belokoņa izdevniecība. 2002. pp. 632, 633.

25 Pētera Stučkas Latvijas Valsts universitāte 40 gados (1919-1959), 1959, p. 9.

26 1919. gada 8. februāra LSPR Izglīitibas komisariāta noteikumi par Latvijas Augstskolu.

27 Ibid. 
of people's university, that is, an institution for further training of adults, similar to those established in, e.g., the Weimar Republic. ${ }^{28}$ It was provided that the students would be obtaining not only a diploma of full education, but also certificates of attending particular study courses. ${ }^{29}$ Different levels of knowledge among students inevitably caused problems in the process of studies. Although the Latvian Higher School only worked for a few months, it encountered considerable difficulties. ${ }^{30}$

There were three governments in Latvia in the spring of 1919: Kārlis Ulmanis' (1877-1942) government, which was supported by the allies, particularly Great Britain; Andrievs Niedra's (1871-1942) government, which was supported by Rüdiger von der Goltz (Gustav Adolf Joachim Rüdiger Graf von der Goltz; 1865-1946) and the German Balts and had the sympathies of Germany; Stučka's government, supported by Soviet Russia. On 22 May 1919, troops loyal to Ulmanis and Niedra jointly liberated Riga from the Bolsheviks. ${ }^{31}$ Almost immediately, changes in higher education took place. Studies at the Soviet Latvian Higher School continued until 21 May 1919..$^{32}$ After the taking of Riga, operation of the Baltic Technical Higher School was renewed, and, after the Ceasefire of Strazdumuiža was signed in July 1919, the Baltic Technical Higher School was closed down. ${ }^{33}$

\section{The origin of the idea of a national university and establishment of the University of Latvia}

The Latvian people managed to preserve the Republic of Latvia, whose foundation on 18 November 1918 was followed by establishment of the Higher School of Latvia. Under the extreme circumstances in the Republic of Latvia, this Higher School was not legally founded as a traditional university, namely, by a special monarch's decision, or a law of parliament, or a government decree, that is, fancy founding documents like the ones that are the pride of universities established before the $20^{\text {th }}$ century ${ }^{34}$ and also later, in a more peaceful time.

28 Dohmen G. Volkshochschulen. In: Handbuch Erwachsenenbildung.Weiterbildung. Hrsg. Rudolf Tippelt. Springer-Verlag, 2013, pp. 408, 409.

29 1919. gada 8. februāra LSPR Izglìtibas komisariāta noteikumi par Latvijas Augstskolu.

30 Pētera Stučkas Latvijas Valsts universitāte 40 gados (1919-1959), 1959, p. 17.

31 Bleiere D., Butulis I., Feldmanis I., Stranga A., Zunda A., 2005, p. 117.

32 Pētera Stučkas Latvijas Valsts universitāte 40 gados (1919-1959), 1959, p. 18.

33 Zigmunde A., 2001, pp. 36-40.

34 A number of legal historians devoted their academic work to studying the foundation documents of universities, e.g.: Bünz E, Graber T. Die Gründungsdokumente der Universität Leipzig (1409): Edition, Übersetzung, Kommentar, Volume 3. Dresden: Publisher Thelem, 2010, Uman L. Die Gründungsurkunden der Prager Universität - Der Sinn der doppelten Bekräftigung des Gründungsaktes. GRIN Verlag, 2011, Conrads N. Die tolerierte Universität: 300 Jahre Universität Breslau 1702 bis 2002; Katalogbuch zur Ausstellung "Die tolerierte Universität". Franz Steiner Verlag, 2004, p. 25. 
The need for education in Latvian was first voiced at the Teachers' Congress in 1905. ${ }^{35}$ In May 1917, the Latvian higher school stakeholders commission, chaired by Miķelis Valters (1874-1968), was established under the Provisional Land Council of Vidzeme. In June 1917 in Dorpat, the Latvian Teachers' Congress set up a Higher School subpanel, which, in turn, created a special Latvian Higher School Committee. ${ }^{36}$ On 11 July 1919, the Higher School panels of the Latvian Education Association decided on the necessity to establish a national higher school. An appeal regarding establishment of the Latvian Higher School was presented to the then Minister for Education Kārlis Kasparsons (1865-1962). ${ }^{37}$ In the interwar period press, 11 July is mentioned as a significant date in the beginning of processes for establishing the University of Latvia. ${ }^{38}$ Furthermore, after World War II, the Latvian exile press refuted the thought that the idea of the need to establish the UL should be associated with the name of Pēteris Stučka. ${ }^{39}$

During the session of the People's Council of Latvia on 15 July 1919, Kārlis Ulmanis spoke about the urgent work to be done by the government in the Republic of Latvia. He said: "As concerns the Latvian Higher School, the works on organising it must be started immediately. The Higher School will start operating on new foundations. The existing Technical Higher School must be taken over by the government. Work on the opening of the University of Latvia must begin. We hope to do it as early as this autumn." 40 The People's Council of Latvia were deciding on establishing the Latvian Higher School by voting on the whole action programme proposed by the Cabinet of Ministers. The deputies voted by standing up: 61 votes were for, while 22 - against the government's action programme. ${ }^{41}$ Thus, the legislator's decision to establish the UL should be dated back to 15 July 1919 . Moreover, the legislator, on the expressis verbis proposal of the head of government, decided to establish a new higher school rather than restore one of the higher schools previously existing in the territory of Latvia.

Next followed the government's action and the organising of the higher school. On 16 July 1919, the People's Council adopted the law on the Cabinet of Ministers' right to issue provisional orders between the sessions of the People's Council in

35 Viča A. Latvijas skolotāju kongress [The Latvian Teachers Congress]. In: Izglìtības Ministrijas Mēnešraksts, No. 2, 01.02.1921, pp. 130, 131.

36 Ozola V. Latvijas Universitātei 55 gadi [The University of Latvia is 55 years old]. In: Latvijas Amerikā, No. 39, 28.09.1974, p. 9.

37 Šodien Latvijas universitātes idejiska dzimšanas diena [Today is the ideological birthday of the University of Latvia]. In: Rits, No. 189, 11.07.1939, p. 17.

38 Ibid.

39 Ozola V., 1974, p. 9.

40 Ulmanis K. Runa Latvijas Tautas Padomes trešās sesijas otrā sēdē. 1919. gada 15. jūlijā [Speech at the second session of the Third Session of the People's Council of Latvia. July 15, 1919]. In: Latvijas Tautas Padomes sēdes, No. 3, 13.07.1919, p. 108.

${ }^{41}$ Latvijas Tautas Padomes trešās sesijas 1919. gada 15. jūlija otrās sēdes stenogramma [Verbatim report of the second session of the Third session of the People's Council of Latvia, July 15, 1919]. In: Latvijas Tautas Padomes sēdes, No. 3, 13.07.1919, p. 121. 
the presence of a pressing need. ${ }^{42}$ The next legal step in establishing the Latvian Higher School was the Government order of 3 August 1919 "On taking over Riga Polytechnical Institute". ${ }^{43}$ This order was recognised as "grounds for the legal existence and further formation of the UL" also in the publication by the Chairman of the UL Organising Council Ernests Felsbergs (1866-1928) and the secretary of the Organising Council Kārlis Oskars Kundziņš (1883-1967) "Explanatory Notes on the Draft Constitution of the University of Latvia". ${ }^{44}$

The order provided for the establishment of a special commission for practical implementation of the order, namely, for 1) taking over the RPI property, 2) discussing the transformation of the RPI departments with the aim to bring them in line with the needs of the newly established Latvian Higher School. ${ }^{45}$ Following the order, the establishing of the Latvian Higher School was commenced. The Government had set the task of opening the Latvian Higher School as early as autumn 1919. Therefore, the respective commissions were established straight away. The first to start its work was the Commission for Reorganising Riga Polytechnical Institute (hereinafter - the Reorganising Commission). Its first sitting took place on 8 August 1919. Concurrently, the Latvian Higher School Deans' Council, Facilities Commission, as well as sub-commissions for founding individual faculties, were established and started working. ${ }^{46}$ In August 1919, a common assembly of former RPI students elected the Students Bureau, which further on participated in the work on establishing the Latvian Higher School. ${ }^{47}$ The Reorganising Commission was tasked not only with taking over the Institute's premises, teaching staff, and students, but also with planning the laying of the foundation of the new Latvian Higher School on the basis of the resources taken over. Already in the first sitting, the commission took decisions not only on what should be taken over from RPI, namely, "first of all, to retain all of the six previously existing faculties: 1) agronomy, 2) engineering, 3) chemistry, 4) trade, 5) architecture, 6) mechanics", but also on what else had to be done for the purposes of the new Higher School, for example, "transforming what was previously the faculty of trade into an economics and law faculty offering a 4-year course". ${ }^{48}$ Also, during the very first sitting, the commission decided on who would have rights to enter the newly established Latvian Higher School. Professor Pauls Valdens (1863-1957) explained that appropriately prepared students, that is, secondary school graduates, are the cornerstone of the Higher School's success.

42 Latvijas Tautas Padomes 1919. gada 16. jūlija Likums par Ministru kabineta tiesību izdot pagaidu rikojumus [Law of the People's Council of Latvia of July 16, 1919 on the right of the Cabinet of Ministers to issue temporary orders]. In: Latvijas Pagaidu Valdỉbas Likumu un Rikojumu Krājums, No. $7,10.08 .1919$, p. 90.1 .

43 1919. gada 3. augusta Latvijas Pagaidu Valdības rīkojums rīkojums Par Rīgas Politehniskā Institūta pārnemšanu [Order of 3 August 1919 on the taking over of the Riga's Polytechnic Institute]. In: Latvijas Pagaidu Valdības Likumu un Rikojumu Krājums, No. 7, 10.08.1919, p. 96.

${ }^{44}$ LVVA 7427. f. 6. apr. 325. lieta, p. 80.

45 1919. gada 3. augusta rīkojums Par Rīgas Politehniskā Institūta pārṇemšanu.

46 LVVA 7427. f. 6. apr. 325. lieta, p. 80.

47 LVVA 7427. f. 6. apr. 37. a lieta, p. 350.

48 LVVA 1632 f. 2 apr. 603. lieta, p. 1. 
Valdens also emphasised the "equal position of young men and young women". 9 In the same sitting, the commission also mapped out the brand new faculties to be established, for whose formation it would be necessary to attract new resources, for example, the faculties of medicine and veterinary science. ${ }^{50}$ The main guidelines developed by the Reorganising Commission for the new Higher School were, as follows:

"1) The Latvian Higher School has to be the highest education institution in the state, resolving all the most important theoretical and practical issues, conducting the relevant academic studies, preparing academic and practical workers useful to the state.

2) While holding the international academia in high respect, in all studies we must seek to consider our specific Latvian circumstances and requirements.

3) Latvian has to be the language of instruction, yet Russian and German are admissible as an exception when renowned foreign professors, or former honorary professors at Riga Polytechnical Institute, are invited to collaborate on a standing or guest basis.

4) Only those Riga Polytechnical Institute honorary professors can be invited as teachers who have not shown hatred and contempt for the State of Latvia, and among younger teachers' preference should be given to Latvian speakers and those familiar with the Latvian environment." 51

On 4 September 1919, the Commission for Reorganising RPI was transformed into the Commission for Organising the Latvian Higher School (hereinafter the Organising Commission). ${ }^{52}$ After the question of taking over RPI had been removed, on 2 September 1919, from the People's Council's agenda for lack of time, ${ }^{53}$ the People's Council of Latvia in the $11^{\text {th }}$ sitting of its fourth session on 5 September decided on the draft law to amend the Government order of 3 August "On taking over Riga Polytechnical Institute." Reporting on the draft was the member of the People's Council Kārlis Dēkens (1866-1942), who explained that the amendments were necessary because, even though the order had provided for the establishment of one commission and invested it with a rather narrow competence, councils and subcommissions had already been created in actual life, participating not only in the takeover of RPI, but also in the establishing of the Latvian Higher School. The proposed amendments were intended to clearly stipulate that "the polytechnical

49 LVVA 1632 f. 2 apr. 603. lieta, p. 1.

50 Ibid.

51 Lejinš P. Latvijas Augstskola [University of Latvia]. Izglītības Ministrijas Mēnešraksts. No. 1. 01.01 .1920 , p. 75.

52 LVVA 7427. f. 6. apr. 325. lieta, p. 80.

53 1919. gada 2. septembra Latvijas Tautas Padomes ceturtās sesijas desmitās sēdes stenogrammas [The shorthand record of the tenth sitting on 2 September 1919 of the fourth session of the People's Council of Latvia]. No. 4, 08.11.1918, p. 164. 
institute is to be transformed into a new Latvian Higher School".54 However, in the debates, the deputies highlighted the internal contradictions in the draft amendments and stressed their low quality. Âdolfs Klive (1888-1974) pointed out that "the Higher School is now at the stage of being organised, and it will have been more fully formed by the next session, so it will be possible to decide if necessary".55 On the whole, the deputies considered the measures for organising the Latvian Higher School to be appropriate and did not see the need to meddle in them unnecessarily with an additional regulation. The draft law was taken off the agenda. ${ }^{56}$

On 16 September 1919, the Organising Commission chaired by Professor Valdens met at the premises of the Ministry of Education to decide on the election of the presidium, selection of teaching staff, student admission, and other issues, including also the opening event of the Latvian Higher School. As follows from the minutes, the Executive Committee for the Higher School opening event was not prepared to report, as the matter was carried over to the next meeting, that is, to 19 September. ${ }^{57}$ On 15 September, the official admission of students into the Latvian Higher School started. ${ }^{58}$ During the meeting on 19 September, the Organising Committee stated that 190 Latvians, 1 Lithuanian, 8 Russians, 7 Germans, 139 Hebrews, or, in total, 345 people wishing to study had applied. ${ }^{59}$ After long disputes during the Executive Committee meetings about the time and date of the Latvian Higher School opening event, the possible deliverers of formal speeches, the venue and the guests to be invited, it was decided that the event would be held on 28 September, first at the premises of the Higher School, then at the National Opera. On 28 September 1919, the first stage of work on organising the Latvian Higher School was concluded, and on 29 September the teaching started. Nearly 2000 students commenced their studies at nine faculties: Architecture, Engineering, Law and Economics, Chemistry, Agriculture, Mathematics and Natural Sciences, Mechanics, Medicine, Linguistics and Philosophy. ${ }^{60}$

The following dates in the establishing of the University of Latvia should be recognised as important from the legal perspective: the decision of the People's Council of Latvia of 15 July 1919 on establishing the Latvian Higher School, and the order [with the force of a law] of 3 August of the Provisional Government of Latvia "On taking over Riga Polytechnical Institute"; also important are the debates

54 The shorthand record of the eleventh sitting on 5 September 1919 of the fourth session of the People's Council of Latvia, proposal of amendments to the order of 3 August 1919 "On taking over Riga Polytechnical Institute". Latvijas Tautas padomes sēdes stenogrammas, No. 4, 08.11.1918, p. 313.

55 Klive, an utterance in debates on amendments to the order of 3 August 1919 "On taking over Riga Polytechnical Institute", the eleventh sitting on 5 September of the fourth session of the People's Council of Latvia. Latvijas Tautas padomes sēdes stenogrammas, No. 4, 08.11.1918, p. 313.

56 Klive, an utterance in debates on amendments to the order of 3 August 1919 "On taking over Riga Polytechnical Institute", the eleventh sitting on 5 September of the fourth session of the People's Council of Latvia. Latvijas Tautas padomes sēdes stenogrammas, No. 4, 08.11.1918, p. 314.

57 LVVA 1632. f. 2. apr. 603. lieta, p. 23.

58 Laube E. Paziņojums [The announcement]. In: Valdïbas Vēstnesis, No. 33, 07.09.1919, p. 3.

59 LVVA 1632. f. 2. apr. 603. lieta, p. 25.

60 Lejiņš P.,1920, p. 75. 
held by the People's Council of Latvia on 5 September to discuss the draft amendments to the government order of 3 August, which allow for the conclusion that the legislator recognised appropriateness of the processes taking place for the UL to be established. These decisions paved the legal grounds for opening of the University of Latvia on 28 September 1919.

\section{Conclusions}

1. In 1918/1919, three statehoods were established in what is now the territory of Latvia, and each of the states founded its own higher school using the Riga Polytechnical Institute's resources that had remained in the territory of Latvia after the evacuation.

1.1. In October 1918, the German occupation power renewed RPI as the Baltic Technical Higher School.

1.2. On 8 February 1919, the Soviet Latvian Higher School was founded by a decree signed by Pēteris Stučka.

1.3. On 15 July 1919, the People's Council of Latvia decided to establish the Latvian Higher School.

2. The analysis of the Latvian Higher School founded by Pēteris Stučka reveals that, pursuant to the Commissariat of Education Regulation of 8 February 1919, equal access to higher education was ensured for all those willing to study, including those who had not received a secondary education. This contradicts the requirements for higher education and raises doubts as to whether a higher school in the traditional sense of the word had been established. The author concludes that what Pēteris Stučka founded was not a classical university but either a Marxist-compatible alternative to the classical "bourgeois university" or a people's higher school where lectures were held in Latvian and Russian.

3. On 15 July 1919, the People's Council of Latvia decided to establish a new Latvian higher school rather than renew one of the higher schools previously existing in the territory of Latvia. For this purpose, on 3 August 1919 the Government issued the order "On taking over Riga Polytechnical Institute", which was followed by activities for the takeover of RPI and the establishing of the Latvian Higher School.

4. The process of establishing the Latvian Higher School concluded on 28 September 1919 with a formal opening event marking the establishment of the first higher education institution - university - in which the language of instruction was Latvian. The Latvian Higher School met the criteria set for universities, as it was stipulated that the School would only admit candidates who have a gymnasium education, and also the teaching staff were required to be appropriately qualified. 


\section{BIBLIOGRAPHY}

\section{Literature and transcripts}

1. Latvijas Augstskola. In: Sociāldemokräts, No. 75, 29.09.1919, p. 1.

2. Šodien Latvijas universitātes idejiska dzimšanas diena [Today is the ideological birthday of the University of Latvia]. In: Rits, No. 189, 11.07.1939, p. 17.

3. 1919. gada 2. septembra Latvijas Tautas Padomes ceturtās sesijas desmitās sēdes stenogrammas [The shorthand record of the eleventh sitting on 2 September 1919 of the fourth session of the People's Council of Latvia]. No. 4, 08.11.1918, p. 164.

4. Bite I. P. "Celdamās augstāki”. Stučkas Latvijas Valsts Universitātei 70 ["Rising higher". Stučka's Latvian State University 70]. In: Literatūra un Māksla, No. 5, 04.02.1989, p. 2.

5. Bleiere D., Butulis I., Feldmanis I., Stranga A., Zunda A. Latvijas vēsture 20. gadsimts [History of Latvia $20^{\text {th }}$ Century]. Otrais papildinātais izdevums. Rīga: Jumava, 2005.

6. Bünz E, Graber T. Die Gründungsdokumente der Universität Leipzig (1409): Edition, Übersetzung, Kommentar, Volume 3. Dresden: Publisher Thelem, 2010.

7. Conrads N. Die tolerierte Universität: 300 Jahre Universität Breslau 1702 bis 2002; Katalogbuch zur Ausstellung "Die tolerierte Universität". Franz Steiner Verlag, 2004.

8. Dohmen G. Volkshochschulen. In: Handbuch Erwachsenenbildung. Weiterbildung. Hrsg. Rudolf Tippelt. Springer-Verlag, 2013.

9. Kaisertelegramm an die Baltische Technische Hochschule. In: Rigische Zeitung, No. 242, 18.10.1918, p. 1.

10. Klive A. An utterance in debates on amendments to the order of 3 August 1919 "On taking over Riga Polytechnical Institute”. In: Latvijas Tautas padomes sēdes stenogrammas, No. 4, 08.11.1918, p. 313.

11. Latvijas enciklopēdija [Latvian Encyclopaedia]. $1^{\text {st }}$ volume. Rīga: Valērija Belokoṇa izdevniecíba, 2002.

12. Latvijas Tautas Padomes trešās sesijas 1919. gada 15. jūlija otrās sēdes stenogramma [Verbatim report of the second session of the Third session of the People's Council of Latvia, July 15, 1919]. In: Latvijas Tautas Padomes sēdes, No. 3, 13.07.1919, p. 121

13. Latvijas Universitāte 1919.-1929. [University of Latvia. 1919-1929] Rīga: Latvijas Universitātes izdevums, 1929.

14. Latvijas Universitāte 20 gados 1919-1939. I daļa, [University of Latvia in 20 years. 1919-1939. Part I] Rīga: Latvijas Universitāte, 1939.

15. Latvijas Universitāte 20 gados 1919-1939. II daļa, [University of Latvia in 20 years. 19191939. Part II] Rīga: Latvijas Universitāte, 1939.

16. Latvijas Universitāte [University of Latvia]. Wikipedia. Available at: https://lv.wikipedia.org/ wiki/Latvijas_Universit\%C4\%81te [last viewed July 11, 2019].

17. Laube E. Paziņojums [The announcement]. In: Valdìbas Vèstnesis, No. 33, 07.09.1919, p. 3.

18. Lazdiņš J. Konstitucionālisma pirmsākumi un nerealizētie valstiskumi Latvijā [The beginning of constitutionalism and unrealized statehoods in Latvia]. In: Jurista Vārds, No. 23 (774), 11.06.2013. Available at: https://juristavards.lv/doc/257350-konstitucionalisma-pirmsakumiun-nerealizetie-valstiskumi-latvija/ [last viewed July 10, 2019].

19. Lejiņš P. Latvijas Augstskola [University of Latvia]. Izglitīibas Ministrijas Mènešraksts, No. 1., 01.01.1920, p. 75.

20. Ozola V. Latvijas universitātei 55 gadi gadi [The University of Latvia is 55 years old]. In: Latvijas Amerikā, No. 39, 28.09.1974, p. 9.

21. Pētera Stučkas Latvijas Valsts universitāte 40 gados (1919-1959) [Peter Stučka’s Latvian State University in 40 years (1919-1959). science editor J. Jurgens. Rigga: Latvijas valsts izdevnieciba, 1959. 
22. The shorthand record of the eleventh sitting on 5 September 1919 of the fourth session of the People's Council of Latvia, proposal of amendments to the order of 3 August 1919 "On taking over Riga Polytechnical Institute”. Latvijas Tautas padomes sēdes stenogrammas, No. 4, 08.11.1918, p. 313.

23. Ulmanis K. Runa Latvijas Tautas Padomes trešās sesijas otrā sēdē. 1919. gada 15. jūlijā [Speech at the second session of the Third Session of the People's Council of Latvia. July 15, 1919]. In: Latvijas Tautas Padomes sēdes, No. 3, 13.07.1919, p. 108.

24. Uman L. Die Gründungsurkunden der Prager Universität - Der Sinn der doppelten Bekräftigung des Gründungsaktes. GRIN Verlag, 2011.

25. Viča A. Latvijas skolotāju kongress [The Latvian Teachers Congress]. In: Izglitîbas Ministrijas Mènešraksts, No. 2, 01.02.1921, pp. 130, 131.

26. Wilhelm I. Graf von Hertling. Anerkennung der Unabhängigkeit von Livland, Estland, Riga und Oesel durch das Deutsche Reich. In: Rigische Zeitung, No. 243, 19.10.1918, p. 1.

27. Zigmunde A. Baltijas Tehniskā augstskola [Baltic Technical University]. In: Zinātņu vēsture un muzejniecība: LU raksti, Vol. 639, Riga: LU, 2001, pp. 36-40.

\section{Legislative acts}

1. 1918. gada 18. novembra Latvijas Tautas Padomes uzsaukums: Latvijas pilsoniem! [The address by the People's Council of Latvia on 18 November 1918: to the nationals of Latvia!]. In: Latvijas valsts tiesỉbu avoti. Valsts dibināšana - neatkarïbas atjaunošana. Dokumenti un komentāri. Rīga: Tiesu namu aǵentūra, 2015, p. 54.

2. 1919. gada 8. februāra Latvijas Sociālistiskās valdības dekrēts "Par Latvijas augstskolas dibināšanu" [February 8, 1919 The Decision of the Latvian Socialist Government "On the Establishment of the Latvian Higher School"]. In: Cina, No. 26, 08.02.1919, p. 1.

3. 1919. gada 8. februāra LSPR Izglītibas komisariāta noteikumi par Latvijas Augstskolu [February 8, 1919 Regulations of the LSSR Education Commission on the Latvian Higher School]. In: Cinna, No. 26, 08.02.1919, p. 1.

4. 1919. gada 16. jūlija Latvijas Tautas Padomes Likums par Ministru kabineta tiesību izdot pagaidu rikojumus [Law of the People's Council of Latvia of July 16, 1919 on the right of the Cabinet of Ministers to issue temporary orders]. In: Latvijas Pagaidu Valdíbas Likumu un Rỉkojumu Krājums, No. 7, 10.08.1919, p. 90.

5. 1919. gada 3. augusta Latvijas Pagaidu Valdības rỉkojums Par Rīgas Politehniskā Institūta pārn,emšanu [Order of 3 August 1919 on the taking over of the Riga's Polytechnic Institute]. In: Latvijas Pagaidu Valdības Likumu un Rỉkojumu Krājums, No. 7, 10.08.1919, p. 96.

6. Latvijas Universitātes Satversme pieņemta LU Satversmes sapulces sēdē 29.03.96. un grozijumi, kas pieñemti LU Satversmes sapulces sēdē 16.12.96., LU Satversmes sapulces sēdē 10.05.2001., LU Satversmes sapulcē 22.02.2006 [The Constitution of the University of Latvia was adopted at a meeting of the Constituent Assembly of the University of Latvia on March 29, 1996. and amendments adopted at a meeting of the Constituent Assembly of the University of Latvia December 16, 1996, at a meeting of the Constituent Assembly of the University of Latvia May 10, 2001, at the Constituent Assembly of the University of Latvia February 22, 2006]. Available at: https://likumi.lv/doc.php?id=46864 [last viewed July 10, 2019].

\section{Archive materials}

1. LVVA 7427. f. 6. apr. 325. lieta, p. 80.

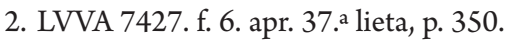

3. LVVA 1632 f. 2 apr. 603. lieta, p. 1.

4. LVVA 1632. f. 2. apr. 603. lieta, p. 25.

5. LVVA 6033, f. 1. apr. 35. lieta, p. 1, 57.

6. LVVA 7427. f. 6. apr. 37. ${ }^{\text {lieta }} 79$, p. 80. 